\title{
Comparison of relative uses of commercial assays for Toxoplasma gondii IgM antibodies
}

\author{
D Ashburn, R Evans, L J Skinner, J M W Chatterton, A W L Joss, D O Ho-Yen
}

\begin{abstract}
Aims: To compare the sensitivity and user friendliness of seven commercially available enzyme linked immunoabsorbent assay (ELISA) kits for toxoplasma specific IgM.

Methods: Five antibody capture assays supplied by Abbott, Mercia, Northumbria, Organon and Sorin, and two indirect ELISA assays from Biostat and Mast, were assessed. Using defined dilutions of Toxoplasma gondii specific IgM, the performance and sensitivity of each assay was established. They were further assessed on a panel of 27 sera with a range of dye test and IgM results (as determined by the Scottish Toxoplasma Reference Laboratory). All of the assays were performed by three experienced operators and assessed for user satisfaction.

Results: The Mast, Organon, and Abbott assays were of low sensitivity; the Mercia and Northumbria were of high sensitivity; and the Biostat and Sorin assays produced too many false positive results. The Mercia kit provided most user satisfaction; the Mast and Abbott assays were most difficult to use.

Conclusions: Local laboratories investigating toxoplasma infection should have three tests: one IgG and two IgM (high and low sensitivity) to help in the timing of infection. Alternatively, one sensitive IgM assay, such as that of Mercia, could be used by selecting appropriate high and low thresholds.
\end{abstract}

The detection of specific IgM antibodies to Toxoplasma gondii is a recognised indicator for recent or current infection. Recently, great public interest has focused on $T$ gondii infection in pregnancy. Many laboratories will be faced with increased demands for tests and it may be difficult for reference laboratories to produce sufficient quantities of their in-house tests. ${ }^{12}$ Therefore, the relative performances and uses of commercial assays require critical assessment, and this information will be of value to many local laboratories.

One major problem in testing pregnant women's sera is determining the time of infection. Infection before conception is not believed to be a great risk to the pregnancy and therefore $\operatorname{IgM}$ persisting from infection before pregnancy may not require treatment. Thus a test which is very sensitive and detects low titres of IgM may have severe disadvantages. ${ }^{3}$ Nevertheless, this same test may be of tremen-
Jous help in detecting cases of congenital toxoplasmosis, even those who present at more than 10 months of age. $^{3}$ The reference laboratory uses several IgM assays and the dye test to come to an informed conclusion on the likely time of infection.

The major considerations are the sensitivity and specificity of individual tests. Obviously, this is best tested in practice with the serum bank available to a reference laboratory. ${ }^{4}$ It is also important to assess how user friendly a commercial kit is. ${ }^{4}$ This study attempts to assess critically the sensitivity of several commercial IgM kits and to determine their relative usefulness.

\section{Methods}

A known $T$ gondii specific IgM positive serum was diluted in serum negative for $T$ gondii specific IgG and IgM. This produced 10 sera for testing: neat, 1 in 5,1 in 10, 1 in 15, 1 in 20, 1 in 25,1 in 30,1 in 35,1 in 40 and 1 in 45. The relative performance of seven commercial kits was compared with the in-house BAMELISA $^{2}$ on three separate runs. Three operators also tested 27 different samples from the serum bank at the Scottish Toxoplasma Reference Laboratory, Raigmore Hospital, Inverness. These sera were chosen to represent a range of dye test and IgM results. On every run sera were tested in duplicate.

The in-house BAM-ELISA ${ }^{2}$ was an antibody capture assay performed in flat-bottomed plates coated with rabbit antihuman ( $\mu$ chain specific) IgM. Following incubation with patient serum, a complex of biotinylated toxoplasma antigen and avidin peroxidase was added. Bound antibody complex was detected using 3,3', 5,5'-tetra-methylbenzidine (TMB) and hydrogen peroxide in citrate acetate buffer (pH6). Incubation was at $37^{\circ} \mathrm{C}$ and the total incubation time was two and a quarter hours. Included in each plate were four each of high positive, low positive, and negative controls. Absorbance was read at $450 \mathrm{~nm}$ against a substrate blank. A test sample was considered positive if the absorbance was greater or equal to the mean of the low positive and negative controls. Equivocal results were those which fell on or above $90 \%$ of the threshold value.

The seven commercial kits comprised five antibody capture and two indirect assays. Test specifications of the seven commercial assays are summarised in table 1 . All tests were performed according to their manufacturer's protocol. Other details of each kit are considered individually. 
Table 1 Comparison of seven commercial kits for detection of specific IgM

\begin{tabular}{|c|c|c|c|c|}
\hline Assay & Solid phase & Conjugate & $\begin{array}{l}\text { Total } \\
\text { incubation } \\
\text { time }(h)\end{array}$ & $\begin{array}{l}\text { Incubation } \\
\text { temperature }\end{array}$ \\
\hline Abbott & Goat antihuman IgM & $\begin{array}{l}\text { Toxoplasma antigens }+ \text { rabbit } \\
\text { antitoxoplasma antigens HRP }\end{array}$ & $3 \cdot 5$ & $37^{\circ} \mathrm{C}$ \\
\hline $\begin{array}{l}\text { Biostat } \\
\text { Mast } \\
\text { Mercia }\end{array}$ & $\begin{array}{l}\text { Toxoplasma antigens } \\
\text { Toxoplasma antigens } \\
\text { Rabbit antihuman IgM }\end{array}$ & $\begin{array}{l}\text { Rabbit antihuman IgM-HRP } \\
\text { Goat antihuman IgM-HRP } \\
\text { Toxoplasma antigens + biotinylated } \\
\text { mouse monoclonal + avidin-HRP }\end{array}$ & $\begin{array}{l}1 \cdot 25 \\
2 \cdot 8 \\
2 \cdot 5\end{array}$ & $\begin{array}{l}\text { Room temperature } \\
37^{\circ} \mathrm{C} \\
37^{\circ} \mathrm{C}\end{array}$ \\
\hline Northumbria & Antihuman IgM (species not specified) & $\begin{array}{l}\text { Toxoplasma antigens then antitoxo- } \\
\text { plasma monoclonal antibody-HRP }\end{array}$ & 3.5 & Room temperature \\
\hline Organon & Sheep antihuman IgM & $\begin{array}{l}\text { Toxoplasma antigens }+ \text { sheep } \\
\text { antitoxoplasma antigens-HRP }\end{array}$ & $2 \cdot 5$ & $37^{\circ} \mathrm{C}$ \\
\hline Sorin & Rabbit antihuman IgM & $\begin{array}{l}\text { Toxoplasma antigens + mouse } \\
\text { antitoxoplasma antigens monoclonal } \\
\text { antibody-HRP }\end{array}$ & $2 \cdot 5$ & $37^{\circ} \mathrm{C}$ \\
\hline
\end{tabular}

The substrate in the Abbott kit was O-phenylenediamine and optical density was read at $492 \mathrm{~nm}$. All of the other assays used $3,3^{1}, 5,5^{1}$,-tetramethylbenzidine and were read at $450 \mathrm{~nm}$.

Abbott TOXO-M EIA Kit (Abbott Laboratories, Maidenhead): Unlike all of the other assays which used microtitre strips, in this assay the capture antibody was coated on to beads. Each run included one high positive, one negative, and three low positive controls. The threshold was taken as half the mean absorbance of the low positive controls. Equivocal results had an absorbance between $40-50 \%$ of the low positive.

Biostat Human (Biostat Diagnostics, Stockport): This indirect immunoassay was performed in strips of eight flat-bottomed wells coated with Toxoplasma antigen. Competition from Toxoplasma specific IgG or rheumatoid factor in the specimen was prevented by incorporating antihuman IgG in the sample diluent buffer. In each run two positive and two negative controls were tested. The threshold value was calculated by adding the mean negative value to a fifth of the positive control value.

Mastazyme -TOXO IgM (Mast Diagnostics, Bootle): This indirect assay was based on Toxoplasma antigen coated strips of eight flatbottomed wells. Specific IgG antibodies were removed by pretreatment with Mastsorb, containing goat anti-human IgG. Duplicate positive and triplicate negative controls were tested in each run. The sum of the mean positive and mean negative control absorbances were multiplied by a factor, supplied with each kit, to produce a cutoff value. Patient sera with an absorbance between the cutoff and $0 \cdot 1$ + cutoff value were considered borderline; those above this range were positive.

Captia TOXO-M (Mercia Diagnostics Ltd, Shalford): This test was based on strips of eight round bottomed wells. Four controls were included in each run; a high positive, a negative, and duplicate low positive controls. The threshold was the mean low positive control value and patient sera within the range $90-110 \%$ of the threshold were considered borderline; those above this range were positive.

Toxenz $M$ ii (Northumbria Biologicals Ltd, Cramlington): This assay was carried out on strips of 12 flat-bottomed wells. One high positive, a negative, and a low positive control were included in each run. Unlike the other assays, this kit required that each specimen was also tested in control wells where antigen had been omitted. Sera having a net absorbance (test well - control well) equal to or greater than the net absorbance of the low positive were considered positive. Sera with a net absorbance between $70-99 \%$ of the net absorbance of the low positive control were considered doubtful positive.

Toxonostika IgM (Organon Teknika, Cambridge): This test used antibody coated strips of 12 flat-bottomed wells. A minimum of two calibrator, two negative, and two positive controls were included in each run. Positive samples were those with an absorbance greater or equal to half the sum of positive and negative controls.

ETI-Toxok-M reverse (Sorin Biomedica, Incstar Ltd, Wokingham): This assay used antibody coated strips of eight flat-bottomed wells. Each run included two positive, two negative, and four cutoff controls. The threshold was the mean absorbance of the cutoff sera. Values within $10 \%$ of the threshold should be repeated.

The assays were rated on several criteria as described by others. ${ }^{4}$ Three experienced operators made their own judgements on four

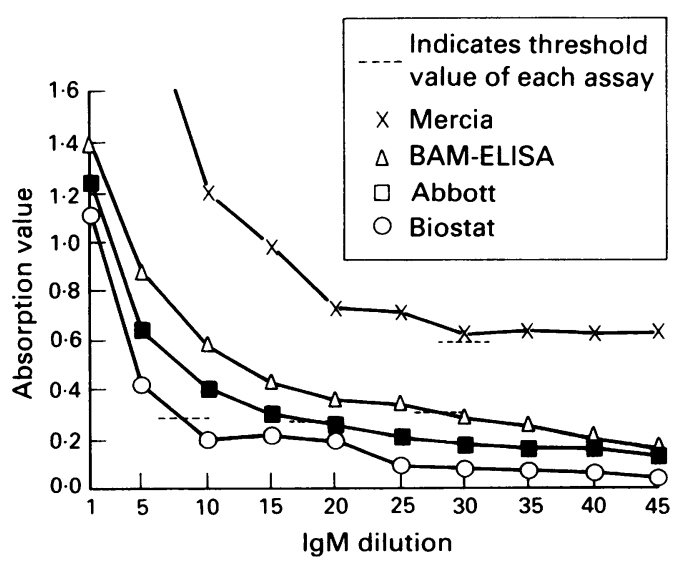

Figure 1 Absorption values of four IgM assays at various IgM serum dilutions from 1 in 1 to 1 in 45 . 
Figure 2 Cutoff dilution for each IgM assay (equivocal range where appropriate)

A-Northumbria,

$B-$ Mercia,

C-BAM-ELISA, $D$-Abbott, E-Organon, F-Sorin, $G$-Biostat, H-Mast.

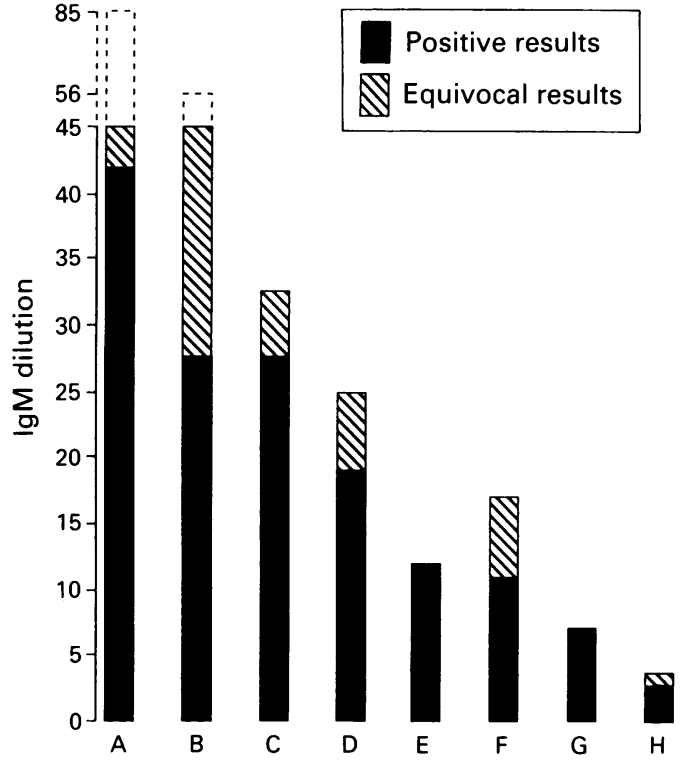

criteria on a scale of $0-4$, with a total possible score of 12 .

\section{Results}

There are clear differences in sensitivity between some of the IgM kits. After three different runs dilution curves were produced as in fig 1. The Organon, Sorin, and Northumbria kits produced curves similar to the Abbott and the in-house BAM-ELISA. The dilution thresholds of these kits ranged from 1 in 12 (Organon) to 1 in 42 (Northumbria). The Mercia kit produced a similar shaped curve, but the absorbance readings for the lower dilutions were much greater than for the other kits. For the dilutions tested its threshold value was not reached (fig 1). Despite this it performed well on selected sera which would indicate a high sensitivity rather than a likelihood of false positive results due to high background readings. The indirect ELISAs (Biostat and Mast) had considerably lower absorbance values and dilution thresholds.

From this information a histogram of sensitivity for each assay was obtained (fig 2). With our diluted IgM serum, the Mast and Biostat assays failed at the 1 in 10 dilution; the Organon, Sorin, and Abbott reliably detected dilutions between 1 in 10 and 1 in 20; the Mercia around 1 in 25 and the Northumbria were able to detect $\operatorname{IgM}$ in dilutions greater than 1 in 40 . When the results of assays were interpreted according to the manufacturer's instructions, the variation in duplicates of each run for all the kits was usually under $10 \%$, and the reproducibility between runs was good for all kits except Biostat.

The results on the selected sera are shown in table 2. Again, the Mast was the most insensitive, followed by the Organon, Sorin, and Abbott assays. Despite its performance on the diluted positive sera, the Biostat proved to be more sensitive in practice. Confirming our dilution experiment, the Mercia and Northumbria assays were the most sensitive. The three tests of low sensitivity (Mast, Abbott, and Organon) and the most sensitive assays (Northumbria and Mercia) produced no false positive results. False positivity was found with the Sorin and Biostat assays.

The user assessment of the assays is shown in table 3. In all categories the Mercia assay scored highest, in particular its colour coding of reagents and its ready-to-use reagents were greatly appreciated. The Mast and Abbott systems scored the lowest total marks, but laboratories that are accustomed to the bead format of Abbott assays may find it more acceptable. With the Biostat assay there were complaints that the strips were fragile and difficult to fit into the holders.

\section{Discussion}

Since the commercial assays were previously assessed ${ }^{45}$ there has been a greater demand for these assays and more kits have become available. We have tested the assays regularly marketed in Britain and the newer versions of established kits. Despite some manufacturers having modified their assays, the relative performance of the kits was similar to that of previous studies. ${ }^{45}$ This suggests that reference

Table 2 Assay results on selected sera

\begin{tabular}{|c|c|c|c|c|c|c|c|c|c|}
\hline \multirow{2}{*}{$\begin{array}{l}\text { Number } \\
\text { of sera }\end{array}$} & \multicolumn{2}{|c|}{ Test sera results } & \multicolumn{7}{|c|}{ Accumulated positive assay results } \\
\hline & Dye test & $B A M E L I S A$ & Northumbria ${ }^{\star}$ & Mercia & Abbott & Organon & Sorin & Biostat & Mast \\
\hline $\begin{array}{l}9 \\
6 \\
4 \\
4 \\
4\end{array}$ & $\begin{array}{l}\text { Raised } \\
\text { Normal } \\
\text { Positive } \\
\text { Positive } \\
\text { Negative }\end{array}$ & $\begin{array}{l}\text { Positive } \\
\text { Positive } \\
\text { Equivocal } \\
\text { Negative } \\
\text { Negative }\end{array}$ & $\begin{array}{l}9 / 9 \\
4 / 6 \\
2 / 4 \\
0 / 4 \\
0 / 4\end{array}$ & $\begin{array}{r}27 / 27 \\
13 / 18 \\
6 / 12 \\
0 / 12 \\
0 / 12\end{array}$ & $\begin{array}{r}21 / 27 \\
5 / 18 \\
0 / 12 \\
0 / 12 \\
0 / 12\end{array}$ & $\begin{array}{r}19 / 27 \\
0 / 18 \\
3 / 12 \\
0 / 12 \\
0 / 12\end{array}$ & $\begin{array}{r}21 / 27 \\
3 / 18 \\
3 / 12 \\
0 / 12 \\
2 / 12\end{array}$ & $\begin{array}{r}25 / 27 \\
13 / 18 \\
6 / 12 \\
2 / 12 \\
0 / 12\end{array}$ & $\begin{array}{r}16 / 27 \\
6 / 18 \\
2 / 12 \\
0 / 12 \\
0 / 12\end{array}$ \\
\hline
\end{tabular}

Assays were run by three operators and results accumulated ${ }^{\star}$ The Northumbria kit was tested once only because half of each kit used was for antigen negative Assays werents.
controls.

Table 3 User assessment of assays

\begin{tabular}{|c|c|c|c|c|c|c|c|}
\hline & \multicolumn{7}{|c|}{ Assay procedure } \\
\hline & Abbott & Mercia & Northumbria & Sorin & Organon & Biostat & Mast \\
\hline $\begin{array}{l}\text { Ease of assay procedure } \\
\text { Clarity of instructions } \\
\text { Presentation and adequacy of reagents } \\
\text { Expression of results and interpretation } \\
\text { Total (possible 48) }\end{array}$ & $\begin{array}{r}5 \\
6 \\
6 \\
5 \\
22\end{array}$ & $\begin{array}{r}10 \\
11 \\
8 \\
9 \\
38\end{array}$ & $\begin{array}{r}6 \\
6 \\
6 \\
6 \\
24\end{array}$ & $\begin{array}{r}9 \\
6 \\
6 \\
9 \\
30\end{array}$ & $\begin{array}{r}9 \\
8 \\
6 \\
9 \\
32\end{array}$ & $\begin{array}{r}6 \\
8 \\
7 \\
6 \\
27\end{array}$ & $\begin{array}{r}6 \\
6 \\
6 \\
4 \\
22\end{array}$ \\
\hline
\end{tabular}


laboratory in-house assays are of a similar and equivalent standard.

Our study concentrated on sensitivity. We believe that it is in the area of the timing of the infection that local laboratories have most problems. If the results of the dilution experiments (fig 2) and those of our selected sera (table 2) are combined, the Mast, Organon, and Abbott assays are of low sensitivity. The Northumbria and Mercia assays have high sensitivity. These five assays produced no false positive results and can be recommended. We feel that the Biostat and Sorin assays produce too many false positive results. Two of the assays (Mast and Biostat) were indirect ELISAs; all of the others were IgM antibody capture methods. It has been suggested that there is little difference between the performance of indirect and antibody capture ELISAs. ${ }^{5}$ However, like others, ${ }^{6}$ we have found that the antibody capture assays are superior.

It is possible for someone to have a primary infection with a low $\operatorname{IgM}$ response because of individual variations. ${ }^{7}$ Thus laboratories require a test with high sensitivity to detect early infections. On the other hand, a sensitive test may reflect infection acquired many months ago and therefore infection before conception. ${ }^{3}$ In these cases it is advantageous to have a test of low sensitivity. We believe that laboratories investigating toxoplasma infection require two IgM tests: one of low and one of high sensitivity. Alternatively, it may be possible to use one IgM test and two threshold levels. For example, the Mercia test is very sensitive (figs 1 and 2). However, by calculating a second threshold so that it has an IgM dilution value of about 1 in 20 , the test will then be comparable with the less sensitive tests. The use of one IgM test may be more practical for those laboratories dealing with a small number of samples. In addition to the IgM tests, an IgG test is required to determine if IgM is early or late. With this combination of tests, together with help from a reference laboratory, a more accurate conclusion regarding onset of infection should be possible.

Three experienced operators used all of the assays. Work was done as part of a busy diagnostic laboratory; thus conditions were likely to be similar to local laboratories. In addition to the considerations in table 3 , each laboratory needs to determine which of the different test formats is most compatible with their existing practices. One important factor is that in laboratories with few IgM tests, it will be far more convenient to have reagents that are already made up and colour coded (Mercia). Although the Northumbria assay scored low marks in user satisfaction, it was the most sensitive assay and produced no false positive results. It is an example of a good product with little consideration for the user.

We are aware that some of our conclusions differ from previous results. We were unable to confirm the false positive results with the Northumbria assay. ${ }^{4}$ It has been claimed that the Abbott assay has a high sensitivity, ${ }^{5}$ but we find that it has a low sensitivity. The explanation is that sensitivity is relative and the previous study did not assess the Mercia or Northumbria assays. The constant arrival of new assays on the market, with their accompanying salespersons, are a source of many queries from local laboratories to reference laboratories. Perhaps it is time for the establishment of a national system for testing new assays.

In conclusion, our results show that the commercial assays have a range of characteristics. Our study has provided detailed, objective information which should be of use to local laboratories. We recommend that those laboratories investigating toxoplasma infection should have three tests: one IgG and two IgM (low and high sensitivity). This study has placed the commercial assays in relevant groups. It is up to local laboratories, with a consideration of their local circumstances, to select the most appropriate assays.

We are grateful to the companies for donating their assays for testing, to Miss V MacFarquhar for secretarial assistance, and to Mr A McGinley for the illustrations.

1 Payne RA, Joynson DHM, Balfour AH, et al. Public Health Laboratory Service enzyme linked immunosorbent assay for detecting Toxoplasma specific IgM antibody. J Clin Pathol 1987;40:276-81.

2 Joss AWL, Skinner LJ, Moir IL, Chatterton JMW, Williams $\mathrm{H}$, Ho-Yen DÓ. Biotin-labelled antigen screening test for toxoplasma IgM antibody. $J$ Clin Pathol 1989;42:206-9.

3 Skinner LJ, Chatterton JMW, Joss AWL, Moir IL, Ho-Yen DO. The use of an IgM immunosorbent agglutination assay to diagnose congenital toxoplasmosis. $J$ Med Microbiol 1989;28:125-8.

4 Joynson DHM, Payne RA, Balfour AH, Prestage ES, Fleck DG. Five commercial enzyme linked immunosorbent assay kits for toxoplasma specific IgM antibody. J Clin Pathol 1989;42:653-7.

5 Verhofstede C, van Renterghem L, Plum J. Comparison of six commercial enzyme linked immunosorbent assays for six commercial enzyme linked immunosorbent assays for detecting lgM antibodies again

6 Herbrink P, van Loon AM, Rotmans JP, van Knapen F, van Dijk WC. Interlaboratory evaluation of indirect enzymelinked immunosorbent assay, antibody capture enzymelinked immunosorbent assay, and immunoblotting for detection of immunoglobulin $M$ antibodies to Toxoplasma gondii. J Clin Microbiol 1987;25:100-5.

7 Wielaard F, van Gruijthuijsen H, Duermeyer W, et al. Diagnosis of acute toxoplasmosis by an enzyme immunoassay for specific immunoglobulin $\mathrm{M}$ antibodies. $J$ Clin Microbiol 1983;17:981-7. 